UDC 177.2:070.16:81'373

DOI https://doi.org/10.32838/2663-6069/2020.2-2/09

Hlavatska Yu. L.

Kherson State University

\title{
RUMOURS AS A PROTOTYPE OF FAKE NEWS: LEXICAL LEVEL
}

The article describes the discursive practices of introducing unconfirmed information into media discourse. Discursive practices are based on English language resources (lexical level) and, accordingly, closely correlate with the genre properties of fake news text. In general, the discourse that uses discursive practices within which unverified information is involved is called anonymous.

The author tries to prove that rumours are the prototype of fake news and serve as an anonymous source of information. In view of media publications discursive practices are constantly pushing authors to refine and find more effective tools for camouflaging untrustworthy information so as not to be exposed and accused of blatant lies. One of the most popular types of unverified information is rumours that realize anonymous information in the media space, and fake news is the good container of false, distorted information. Rumours are an important source of knowledge about what is happening in society in general, in politics in particular; rumours are a special source of information, because it is rumours that people trust; it is a kind of reflection of the socio-psychological, sociopolitical, socio-economic and socio-cultural situation in society.

The article deals with the general scientific methods of synthesis, analysis and methods of linguostylistic analysis of fake news texts. The article defines "rumours" and explains the semantics of this lexical unit using the method of thesaurus analysis. Component analysis of the data presented in the article shows that semantization of the word "rumours" is carried out on the basis of categorization according to the following criteria: 1) communicative status; 2) nature of communication; 3) channel of information transmission; 4) type of communication situations; 5) source of origin information; 6) the degree of reliability of the information; 7) the degree of verification of the message; 8) the extent of information dissemination.

According to the results of the lexico-semantic analysis we distinguish three groups of lexemes for the designation of false anonymous content: absolute, relatively reliable and completely reliable rumours.

Key words: anonymous information, informal communication, media text, media discourse, communicative status, information transmission channel.

Introduction. We often forget that false content is not so much an obstacle to distribution as an advantage, because the reader gets what he wants to hear as a result. Fakes attracted widespread attention, especially after the presidential elections in the USA and France, when they were actively used for or against candidates. Although besides this there were referenda (Brexit and Catalonia), and the struggle to interpret the catastrophe of the Malaysian Boeing $\mathrm{MN}-17$, and even against vaccination in the USA.

G. Pocheptsov distinguishes at least three factors that have pushed fakes to such a new position. Firstly, fakes are a deviation from the truth, at least in its traditional understanding with which mankind has lived all the time. We can conditionally say that the fake is the truth of lie, because people perceive it as the truth, and this is a very important factor. Secondly, fakes turned out to be widespread enough in information flows to be noticed. And since they are common, it means that they are needed either to a communicator, or to a recipient of information. That is, fakes turned out to be such a necessary symbiosis for two parties. Thirdly, fakes and memes today function as rumors and jokes of yesterday, they can be defined as structures with an "engine", since they are capable of self-distribution [5, p. 57].

A comprehensive study of "fake" news as a genre of modern English-language media discourse has been presented in works by Yu. Omelchuk. The scientific focus is on the description of the linguocognitive and communicative-pragmatic parameters of pseudo news [4]. We have also attempted to describe the historical basis for the development of fake news features [2] and the dominant ways of the comic actualization of irony and sarcasm as the types of comic sense, humour and satire as full forms of the comic in "fake" news [8].

The objective of this scientific paper is to find profound evidence to prove rumours are the prototypes of fake news as one of fake news background features is presenting anonymous information. To realize the objective we should refer to the definition 
of rumours meanings and describe their actualization in fake news texts.

Discussion. Attention to fakes revives interest in scientific works on rumours. The rumours distinguish two main characteristics. On the one hand, they do not have specific standards of evidence, so the line between information and deception is erased. On the other hand, rumors are not just borderline representations; they gain their strength through widespread dissemination and repetition. As seen, the second feature generally characterizes fakes [5, p. 64].

In order to prove that rumours are the sources of anonymous information and the prototype of modern fake news we must analyze the lexeme "rumour" using the method of thesaurus analysis. According to lexicographical sources a set of verbal means of "rumour" is quite diverse: from monosyllabic nominations of different parts of linguistic affiliation to phrase units (complex words, phrase verbs, phrases, phraseologisms).

Longman Dictionary of Contemporary English gives such a definition of rumours: "information that is passed from one person to another and which may or may not be true, especially about someone's personal life or about an official decision" [9, p. 1241]. Longman Dictionary of English language and Culture defines rumours in such a way: "unofficial news or information, perhaps untrue, which is spread from person to person; hearsay; a story or opinion based on rumour, which may or may not be true" [10, p. 1181]. The American English Dictionary states that rumors are " a piece of unverified information of uncertain origin usually spread by word of mouth; unverified information received from another; hearsay" [12]. The analysis of other definitions of rumours proves that the semantization of the lexeme is carried out on the basis of categorization according to the following criteria: 1) communicative status; 2) nature of communication; 3) channel of information transmission; 4) type of communication situations; 5) sources of origin of information; 6) the degree of credibility of the information; 7) the degree of verification of the message; 8) the scale of information dissemination.

The invariant semantic elements of the definitions of the word-concept "rumours" based on the proposed parameterization are the following: 1) "informational message"; 2) "oral nature of communication"; 3) "interpersonal channel of information transmission"; 4) "informal type of communication situations"; 5) "anonymity of the source of information"; 6) "the wide amplitude of the transmission of information: from true to false"; 7) "extremely low degree of ver- ification of (confirmed) information transmitted"; 8) "wide circulation of information".

In addition to these characteristic semantic elements based on the selected parameters, one of the interpretations introduces an additional criterion that thematizes the content of the rumours and distinguishes the semantic component ("the big problem of what is being discussed: from the private life of individuals to significant social events") [10].

However, rumours as an element of social and psychological knowledge are the object of scientific interest of representatives of different humanitarian fields. They extensively study the various aspects of this multidimensional construal. Thus, rumours position themselves as: 1 ) a social phenomenon (a form of public opinion); 2) a psychological tool (a way of manipulating public consciousness); 3) a means of political struggle (a product of information warfare); 4) the cognitive construal (the carrier of "shadow" information, on the one hand, and the indirect manifestation of the collective unconscious, on the other); 5) the phenomenon of interpersonal communication (a special type of informal communicative behaviour).

The latter approach, that is, the study of rumours in the status of a specific communicative unit of interpersonal communication, is implemented within the framework of mass communication theory, and the need for research of rumours in this perspective does not raise any doubts about the active development of representatives of different scientific schools such notions as "adaptability", "discursive weapons", "information war", "conflicting discourse".

Attempts to define the concept of "rumour" in the context of the communicative paradigm can be reduced to the following options: 1) "element of other communicative behaviour", "message that is being broadcast"; 2) "recurrent form of communication"; 3) a variety of indirect information; 4) unit of realization of anonymous information.

L. Klymanska believes that "rumours is an important source of knowledge about what is happening in society in general, in politics in particular"; "rumours is a special source of information, because it is rumours that people trust"; "this is a kind of mirror of socio-psychological, socio-political, socio-economic, socio-cultural situation in society" [3].

Rumours are considered a kind of the so-called indirect communication. The most important quality of any indirect information is its active involvement in the creation of meaningful text space. It is known that any alien text fragment or quotation, getting into the intertextual space, acquires a second life 
and, depending on the author's setting, the purpose of the discourse, specific conditions of the context, may undergo substantial semantic modifications as a result of the inaccuracy of the transmission - from the insignificant distortions of the information being reported to giving it the exact opposite content. At the same time the author of anonymous information by skillful submission of it makes not direct, aggressive, but veiled management of the recipient's consciousness, his knowledge, judgments, values, ideology, as well as emotions and mood. This provides the main purpose of the media: managing the mass consciousness through public discourse means managing the actions of the addressee.

In order to distort the objective state of affairs deliberately the author of a message working in the media, first of all, is confronted with the task of producing a special discourse that has a set of textual criteria related to stereotyped models of presenting such information. To realize this aim, first, it is necessary to distinguish linguistic factors: the specificity, character, grammatical structure and lexical-semantic resources of a particular language, which significantly facilitate the implementation of the installation in linguistic practice. Thus, it is possible to distinguish discursive practices related to the peculiarities of language structure. Second, there are a number of practices that deal with the genre-specificities of media text. Third, it is advisable to refer to the whole text in order to pay attention to the textual categories of informativeness and modality, which will signal about the implementation of discursive practices at the textual level.

To confirm the assumption of multiple levels of submission of unverified information, let us turn to the media discourse, first of all, to establish the most popular language-based text creation strategies typical of English-language publications. According to our observations English has a wide system range of multilevel means of processing unverified information.

Observing the means of presenting anonymous information in political communication allows us to distinguish three of their main types: based on rumours per se, translatability and the inferiority of information.

In modern media space there are a lot of English-language publications that create a special culture in society - the so-called "culture of political scandal". According to American sociologists this culture can be imagined today as a phenomenon that is capable of self-replicating and self-reproducing. Journalists and researchers working in the field of mass media fully justify the use of rumours in the media, since, in their view, the rumours help to track new information and are a manifestation of a natural human interest. Moreover, there is a view that even rumours of negative content can be viewed in a positive way because they serve as a lubricant in the process of social interaction of people.

Of course, this phenomenon is closely linked to the creation of anonymous discourse on the basis of media, that is, a discourse within which materials based on information that have no established authorship are considered acceptable. We think it expedient to consider the manifestation of the speculation of rumours at different levels of language, which can be directly traced in the texts of fake news.

The most obvious form of rumours in anonymous discourse is lexical units. The use of the thesaurus method of analysis has allowed us to conclude that the English language has in its arsenal a well-developed system of lexical units to denote this type of information. Ways of submitting unverified information may differ not only in the degree of indication of such information, but also in the degree of mitigation of knowingly negative information in the media. English dictionaries provide a fairly diverse list of units that can be used to design anonymous information: "announce, blab, break the news, breathe, bring word, bruit, bruit about, buzz, canard, chat, circulate, common talk, cry, flying rumor, give a report, give tidings of, gossip, grapevine, rehearse, relate, report, reveal, roorback, rumble, rumor, say, scoop, scuttlebutt, suggest, susurration, talk, tattle, tell, tidings, tittle-tattle, town talk" and others [11].

Nowadays new forms of political rumours have emerged, reflecting changes in politics, media and culture. Their interaction has led to the creation of a new kind of culture - "convergence culture", which denotes a modern form of rapprochement of cultures, somewhat similar to "culture scandal".

The above lexemes are used in political information to frame the absolute rumours in their most obvious form:

(1) "He alleged that the father of Ted Cruz, his challenger for the nomination, was involved in the assassination of President John F. Kennedy, and perpetuated the false claim that President Barack Obama was not born in the United States" [13].

(2) "Trump and his allies have repeatedly made unfounded and false claims to allege that the Bidens acted corruptly in Ukraine" [6].

(3) "They have transformed the political media system, and redefined the role of $\langle\ldots\rangle$ the election were infused with misinformation, baseless rumors, and outright lies" [13]. 
The units highlighted in the examples clearly indicate that the information being reported is rumoured: the words "alleged" and "to allege" (Example 1,2) are defined as "said, without proof, to have taken place or to have a specified illegal or undesirable quality". In Example 3 the key lexeme "rumour" is used to convey information.

The second group includes units that designate the rumours as relatively reliable. In such cases, the author reports information which, in his opinion, is not clearly untrue. Often, a source of information is a representative of institutional channels, although for obvious reasons, he is not identified:

(4) "But one prominent Republican however appeared to signal a campaign of revenge against political foes who brought the President to this point" [6].

(5) “An Arab League statement released Saturday was tougher, pledging no cooperation with US efforts to enforce the plan "in any way or form»" [6].

To make the message formal the authors mention some (using the English indefinite article and the numeral "one") diplomats, politicians, officials as we can trace in Examples 4 and 5.

Finally, anonymous information can be framed as credible when it arrives through official channels with links to reputable periodicals, government agencies or exact representatives of the government:

(6) "When asked why Bloomberg had made the decision to drop $\$ 10+$ million on a single 60-sec- ond ad during the Super Bowl, a campaign spokesman told The New York Times: "The biggest point is getting under Trump's skin»" [6].

(7) "A Canadian citizen was turned away at the US' northern border as a part of President Donald Trump's temporary ban on people who have visited China before their arrival in the United States, acting Homeland Security Deputy Secretary Ken Cuccinelli said Monday" [7].

As we can see, in Example 6, the author refers the reader to a valid news source, The New York Times. Example 7 is supported by the indirect language of the US Deputy Secretary of Homeland Security, Ken Cuccinelli. The nature of the veracity of the message also provides the use of punctuation citation: "«We're just beginning, today, to see results of implementation», said Cuccinelli, who serves on the President's coronavirus task force" [6].

Conclusions. Rumors in the press today are an important tool of myth making, which confirms R. Barthes' view that myth is "not a vestige of archaic consciousness, but a huge part of modern culture" [1, p. 75], including the culture of political field and media. Thus, the so-called "followers" of rumours fake news as a medium of communication, with their range extending - from innocent play to deliberate deception appear.

The perspective of further investigation is the description of verbal means of anonymous information on syntactic level.

\section{References:}

1. Барт Р. Миф сегодня. Барт Р. Избранные работы. Семиотика. Поэтика. Москва : Прогресс ; Универс, 1994. С. 72-130.

2. Hlavatska Yu. L. "Fake" news functions: historical background of their development. Науковий вісник Херсонського державного університету. Серія «Лінгвістика». Херсон, 2018. Вип. 34. Т. 2. С. 150-152.

3. Климанська Л. Д. Чутки як спосіб організації та самоорганізації інформаційного простору політики. URL: http://vlp.com.ua/files/15_69.pdf (дата звернення: 03.02.2020).

4. Омельчук Ю. О. Псевдоновини як жанр сучасного англомовного медіадискурсу: лінгвокогнітивний, комунікативно-прагматичний параметри : дис. ... канд. філол. наук : 10.02.04. Запоріжжя, 2018. 230 с.

5. Почепцов Г. Г. Дезинформация. Киев : ПАЛИВОДА А. В., 2019. 248 с.

6. Iowa vote collides with impeachment trial in epic clash. $C N N$. URL: https://edition.cnn.com/2020/02/03/ politics/trump-senate-impeachment-trial-iowa-caucuses/index.html (date access: 03.02.2020).

7. Top U.S. diplomat launches f-bomb on EU in leaked recorded conversation. CNN. URL: https://security.blogs.cnn. com/2014/02/06/top-u-s-diplomat-launches-f-bomb-on-eu-in-leaked-recorded-conversation (date access: 04.02.2020).

8. Hlavatska Yu. L. "Fake" news via the comic: distortion of information. Modern development trends in philology and social communication : collective monograph. Lviv ; Toruń : Liha-Pres, 2019. P. 18-33.

9. Longman Dictionary of Contemporary English. London : Longman, 2000. 1668 p.

10. Longman Dictionary of English Language and Culture. London : Longman, 1999. 1568 p.

11. Moby Thesaurus. Englishtips.org. URL: http://englishtips.org/1150798577-moby-thesaurus.html (date access: 20.03.2020).

12. The American Heritage Dictionary of the English Language. URL: http://americanheritage.yourdictionary. com (date access: 05.02.2020).

13. Owen D. The New Media's Role in Politics. OpenMind. URL: https://www.bbvaopenmind.com/en/articles/ the-new-media-s-role-in-politics/ (date access: 03.02.2020). 
ГЛавацЬКа Ю. Л. ЧУТКИ ЯК ПРОТОТИП ФЕЙКОВИХ НОВИН: ЛЕКСИЧНИЙ РІВЕНЬ

У статті пропонується опис дискурсивних практик упровадження непідтвердженої інформачії в медійному дискурсі. Дискурсивні практики базуються на мовних ресурсах англійської мови (лексичний рівень) та, відповідно, щуільно корелюють із жанровими властивостями новинарного тексту фейкових новин. Загалом дискурс, що використовує дискурсивні практики, у межах яких виявлясться задіяною неверифікована інформачія, пропонується називати анонімним.

Автор намагається довести, щзо чутки лежать у підгрунті створення фейкових новин і постають джерелом подачі анонімної інформачії. 3 огляду на медійні публікачї дискурсивна практика постійно підштовхує авторів до вдосконалення та знаходження більш ефективних інструментів камуфлювання недостовірних відомостей із метою уникнення викриття й звинувачення в явній брехні. Одним із найпопулярніших видів неперевіреної інформації є чутки, які реалізують анонімну інформацію в усемережжі, а фейкові новини є тим вдалим контейнером, який вміщує неправдиву, перекручену інформацію. Чутки - иее особливе джерело отримання інформації, оскільки саме чуткам люди довіряють.

У статті залучено загальнонаукові методи синтезу, аналізу та методологічний інструментарій лінгвостилістичного аналізу новинарних текстів фейкових новин.

У роботі надано визначення чуток та розтлумачено семантику иієї лексичної одиниці із залученням методу тезаурусного аналізу. Компонентний аналіз наведених у статті даних свідчить про те, що семантизачія лексеми «чутки» здійснюється на основі категоризаџї̈ за такими критеріями: 1) комунікативним статусом; 2) характером комунікації; 3) каналом передачі інформації; 4) типом ситуачій спілкування; 5) джерелом походження інформації; 6) ступенем достовірності відомостей; 7) ступенем верифікаиії повідомлення; 8) масштабом поширення інформації. За результатами лексикосемантичного аналізу ми виокремлюємо три групи лексем на позначення фальшивого анонімного контенту: а) оформлення абсолютних чуток у найбільш очевидній їхній формі; б) оформлення чуток як відносно достовірних; в) анонімну інформачію, оформлену як иілком достовірну.

Ключові слова: анонімна інформачія, неформальна комунікачія, масмедійний текст, медійний дискурс, комунікативний статус, канал передачі інформачії. 